\title{
U.S. International Trade and Financial Developments in 1976
}

\author{
DONALD S. KEMP
}

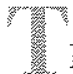
敾. HE purpose of this article is to review U.S. international trade and financial developments for the year 1976. However, because much of the data relating to these developments are not available beyond the second quarter of 1976 , the review is limited in this respect. Since this same limitation was encountered in the Review article which examined international transactions for the year 1975 , the events of the last half of 1975 will be briefly recounted here. ${ }^{1}$ of particular importance is the pattern of international transactions, their impact on the U.S. economy, and consideration of the movement of exchange rates between the U.S. dollar and other major currencies. In this regard attention will be devoted to the Italian lira, the British pound, and the Mexican peso.
\end{abstract}

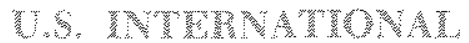

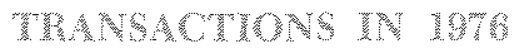

\section{What Waprened}

Reference to the figures presented in Table $I$ indicates that merchandise exports increased during the third and fourth quarters of 1975 by $\$ 711$ million and $\$ 1.1$ billion, respectively. ${ }^{2}$ However, during the first quarter of 1976 merchandise exports declined by $\$ 821$ million. This decline was evenly divided between agricultural and non-agricultural goods. A decrease in capital goods exports, led by a decrease in the export of civilian aircraft, accounted for most of the decline in non-agricultural exports. However, merchandise exports registered a significant turnaround during the second quarter of 1976 , increasing by $\$ 1.6$ billion. While both agricultural and non-agricultural exports increased during this quarter, the latter category accounted for about two-thirds of the total increase. This was primarily the result of a large increase in capital goods exports, led again by civilian aircraft.

\footnotetext{
ISee Hans H. Helbling, "Foreign Trade and Exchange Rate Movements in 1975," this Reviet (January 1976), pp. 9-14.

-For a description of the various categories of international transactions discussed in this article, see any issue of $U . S$. International Transactions and Currency Review, published quarterly by this Bank.
}

Merchandise imports increased during each quarter from III/75 to II/76. During both the first and second quarter of 1976 the major part of the increase occurred in the industrial supplies and materials com. ponent. While petroleum imports increased in both quarters, the second quarter increase in these imports was particularly large, accounting for nearly all of the increase in merchandise imports in that period.

Preliminary data indicate that both merchandise exports and imports increased during the third quarter of 1976, with the latter increasing substantially more than exports. Indications are that these increases were broadly based across virtually all categories of imports and exports.

The flow of direct investment between the United States and the rest of the world changed significantly between II/75 and II/76. Over this four quarter period, U.S. direct investment abroad increased in two quarters ( $\$ 924$ million in $I V / 75$ and $\$ 63$ million in $I / 76)$ and decreased in two quarters ( $\$ 1.6$ billion in III $/ 75$ and $\$ 2.2$ billion in II/76) relative to the levels recorded in the respective preceding quarter. Direct investment in the United States also decreased during two quarters ( $\$ 828$ million in III/75 and $\$ 2$ billion in $1 / 76$ ) and increased in two quarters (about $\$ 1.3$ billion during $I V / 75$ and $I I / 76$ ) relative to their respective levels in the preceding quarter. In fact, during III/75 and I/76 foreign direct investment in the United States was actually negative. The $\$ 728$ million disinvestment recorded in $I / 76$ was a record decrease for the post-war period. However, during $I I / 76$ the flow of direct investment into the United States increased to record a net inflow of $\$ 547$ million. At the same time, U.S. direct investment abroad decreased relative to its first quarter rate, to register a net decline of $\$ 463$ million. This was the first quarter since at least the early $1960^{\prime} \mathrm{s}$ during which there was a net U.S. direct disinvestment abroad. Thus, during the first half of 1976 there was a significant shift in direct international investment from a net U.S. outflow in the first quarter to a net U.S. inflow in the second quarter. 
toble

\section{US. NTERNATIONAL TRANSACTIONS} Seasonally Adiusted

(killons of Dollors)

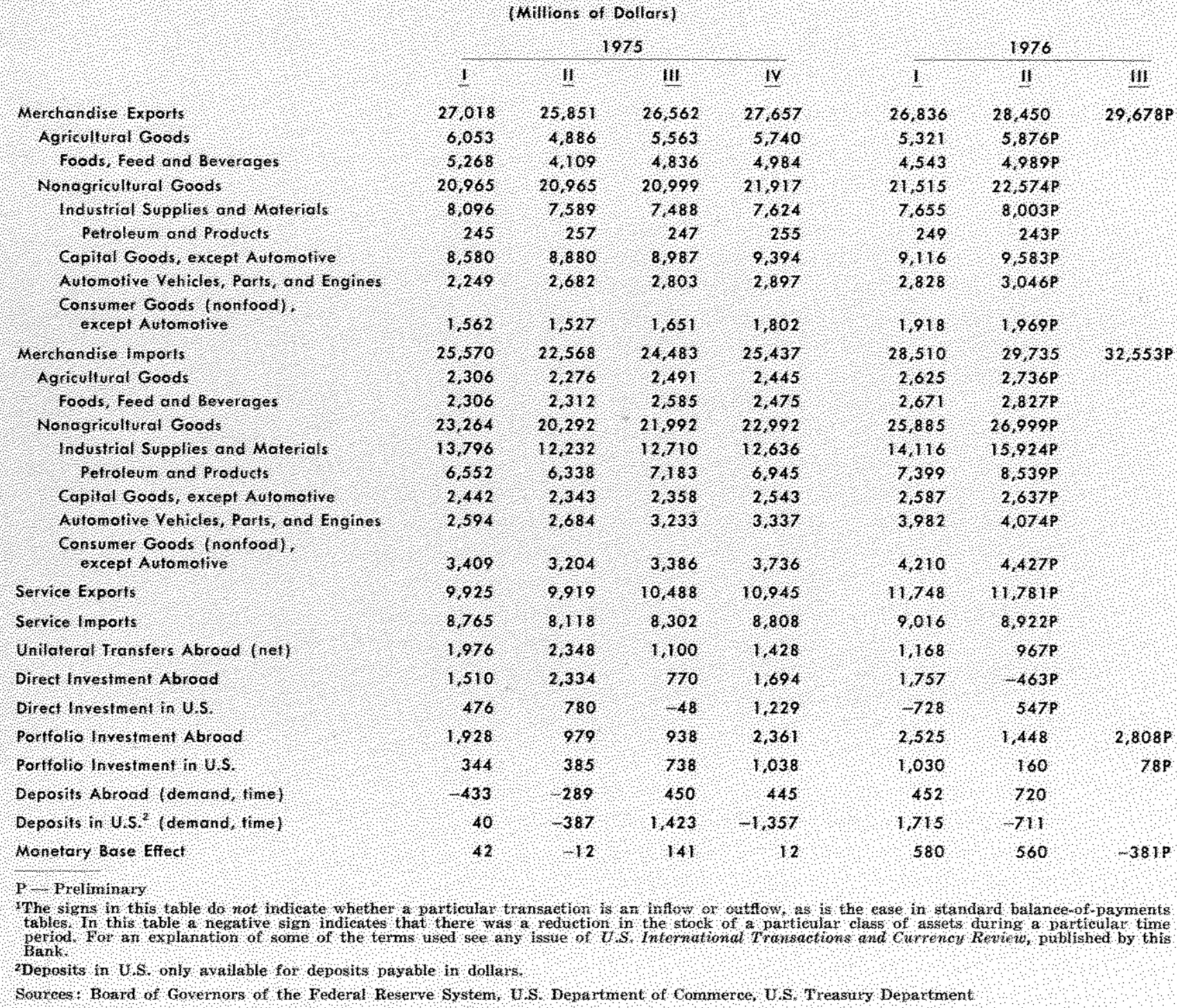

U.S. portfolio investment abroad followed the same general pattern as U.S. direct investment, rising during $I V / 75$ and $I / 76$ and declining during $I I I / 75$ and II/76. However, unlike U.S. direct investment abroad, there was still a net increase in portfolio investment abroad of about $\$ 1.4$ billion in the second quarter. On the other hand, foreign portfolio investment in the United States slowed during the first three quarters of 1976 after increasing during the last two quarters of 1975 . However, as was the case with portfolio investment abroad, there was a net increase in portfolio investment in the United States during all three quarters of 1976.
United States ownership of bank deposits abroad increased during each quarter after the second quarter of 1975. However, while foreign owned bank deposits in the United States increased significantly during $I I / / 75$ and $1 / 76$, there was a decline in these deposits during IV/75 and $I I / 76$.

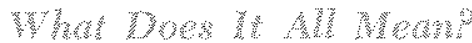

In spite of many attempts to do so in the past, it is almost impossible to glean an overall picture of the impact of international transactions on the U.S. economy from the data discussed in the preceding section. 
The data are partial in coverage and are, therefore, a very incomplete guide to an assessment of the overall impact of international transactions on economic activity. However, the data can be very useful in an assessment of international investment trends and a more specific breakdown of the merchandise trade accounts could be useful for specific industry studies.

In order to assess the overall impact of international transactions on the U.S. economy, it is necessary to compute the net impact of these transactions on the U.S. money stock. Under a system of "managed" exchange rates, the primary chamnel by which international trade and capital transactions can have an impact on aggregate economic activity is via international reserve flows and their subsequent impact on the money supply." However, one is unable to gauge the magnitude of this impact by looking at either the trade or the capital account separately. For example, the effects on aggregate economic activity of a deficit in the merchandise trade account alone could be partially or fully neutralized by a surplus in one of the capital accounts. If such a situation arose, the negative aggregate demand (for domestic output) effects resulting from an increase in imports of goods would be partially or fully offset by an inflow of capital and a resulting increase in investment demand. If the two effects fully offset each other, there would be no gain or loss of international reserves and the money supply would not be affected by the international trade and capital transactions.

Of all international transactions, the only ones that affect the money stock are those that affect some component of the monetary base. Official U.S. hold. ings of gold and foreign currency balances (primary reserve assets) and foreign deposits at Federal Reserve Banks are the only components of the monetary base that are affected by intemational transactions. Thus, the entire impact of these transactions on the money stock can be captured by observing changes in these items. ${ }^{4}$

The computations described above have been performed and the results are presented in Table I

\footnotetext{
3 A system of "managed" exchange rates is one in which exchange rates are managed through limited official market intervention rather than rigidly pegged or left alone to float completely free in response to nongovernmental market influerces. This type of arrangement is descriptive of the approach taken by the United States since Match, 1973.

FFor a nore thorough exposition of this view, see Donald $S$. Kemp, "A Monetary View of the Balance of Payments," this Review (April 1975) , , 16 and "Balance-of-Payments Concepts - What Do They Really Mean?" this Review (July $1975)$, p. 16.
}

under the heading "Monetary Base Effect". These figures indicate that the net impact of international transactions during each quarter from III/75 to II/76 was to exert upward pressure on the monetary base and, therefore, on the money stock. During the third quarter of 1976 these transactions exerted downward pressure on the monetary base on the order of $\$ 381$ million. However, when these figures are compared with the overall changes in the monetary base over these periods, their significance is brought into better perspective. In the four quarters from III/75 to II/76, the monetary base effect amounted to $6.6,0.6,34.6$, and 21.4 percent, respectively, of the total increase in the monetary base. In the third quarter of 1976, the negative impact on the base amounted to 19.4 percent of the total change.

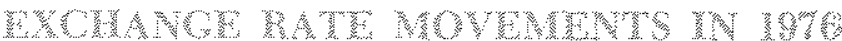

The year 1976 has been a watershed in the annals of international monetary reforms. The events of 1976 represent a de facto as well as a de jure defeat for the advocates of artificially pegged exchange rates. For those who have long recognized the futility and folly of such policies, the events of 1976 were evidence of an ideological triumph.

The de facto defeat of the advocates of fixed exchange rates is represented by the precipitous decline in the international value of the Italian lira, the British pound, and the Mexican peso. These events are a grim testimony to the unacceptability of fixed exchange rates between countries which pursue differing domestic economic policies. This unacceptability was further demonstrated during 1976 by the recurrence of exchange market crises that plagued efforts to hold together the European Currency Snake. The de jure defeat of the fixed rate advocates came in the form of a proposed amendment to Article IV of the Articles of Agreement of the International Monetary Fund (IMF). The proposed amendment to Article IV not only legalizes floating exchange rates, but also requires that IMF members avoid manipulating exchange rates..$^{.0}$

The depreciation of the pound, the peso, and the lira can be explained in terms of relative rates of

\footnotetext{
5 By allowing exchange rates to float, most IMF members have been acting in violation of Article IV for some time. In its current form, Article IV prohibits the current international monetary atrangement of managed floating. However, the amended Article IV, which allows floating, is more representative of the sentiments of most IMF members and will probably, therefore, be ratified in the near future.
} 
inflation. ${ }^{6}$ In other words, movements in exchange rate can be thought of as a means of adjusting price levels for the effects of differing actual or expected rates of inflation between two countries. As one country inflates faster than another, the value of that country's currency falls (depreciates) relative to the value of the low inflation country's currency. Under a system of freely floating or loosely managed exchange rates, necessary adjustments to differing rates of inflation are permitted to occur gradually. How.ever, when exchange rates are narrowly fixed (as was the case with the Mexican peso prior to September 1976) or tightly managed (as has been the case with the Italian lira and the British pound since March 1973) exchange market pressures axe not relieved in a slow and orderly fashion. However, once market participants sense the presence of pent-up market forces which favor realignment, exchange market pressures surge and result in "currency crises" and sudden large jolts in exchange rates. Thus, while the relationship between exchange rates and relative rates of inflation may not be strong in the short run, the longer the time frame, the stronger this relationship becomes.

\section{n}

The exchange rate between the Italian lira and the U.S. dollar provides a good example of the affects of differing rates of inflation among trading partners. Chart I attempts to illustrate this point graphically. Using March 1973 as a base, an index of the level of wholesale prices is plotted for the United States (labeled U.S. WPI) and for Italy (labeled Italy WPI). The divergence of these two lines over time indicates that inflation has been greater in Italy (105 percent) than in the United States ( 44 percent) since March 1973. If the lira/dollar exchange rate were to change enough to compensate for these differing rates of inflation, the result would be a depreciation of the lira vis-a-vis the U.S. dollar by an amount equal to the spread between the two wholesale price lines (about 61 percentage points). ${ }^{7}$

To see if this has been true, the following computations were performed. First an index of the exchange

"For a more complete specification of the relative inflation rate explanation of exchange rate changes, see Donald $S$. Kemp, "The U.S. Dollar in International Markets: Mid-1970 to Mid1976," this Review (August 1976), p. 12.

rSuch a depreciation of the lira would mean that the purchasing power of the lira was the same in both the United States and Italy. If the lira did not depreciate in the face of the higher Italian inflation, then the purchasing power of the lina would be higher in the United States than it would be in Italy.

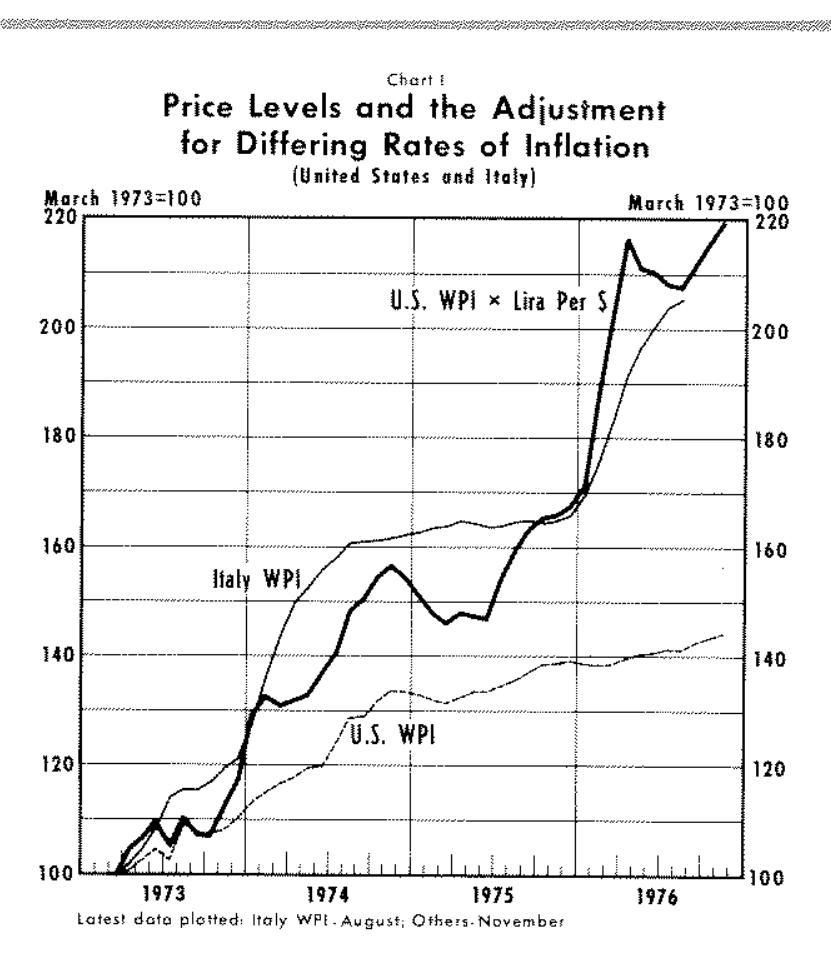

rate (expressed as lira per dollar) was constructed using March 1973 as a base. The U.S. wholesale price index was then multiplied by the exchange rate index in each month through November 1976. The resulting product series was then plotted on Chart I (labeled U.S. WPI $\times$ lira per \$). If exchange rates changed to compensate for differing rates of inflation, then this line (henceforth referred to as the product line) should trace along the Italy WPI line. On the other hand, if the exchange rate did not change at all, the product line would trace along the U.S. WPI line.

Chart I indicates that over the long run the product line has traced the path of the Italy WPI line. As mentioned previously, this relationship should not be expected to hold up in the short rum. Inflationary pressures become established only in the long run and the full impact of differing inflation rates can be resisted by governments in the short run. However, with isolated incidents acting as catalysts to precipitate shortrun surges in exchange rates, inflation rate differentials will exert themselves in the long run. ${ }^{\mathrm{s}}$

In the case of Italy, the product line traces the rise in the Italy WPI line fairly closely, with the most

8Many of the specific events mentioned as affecting exchange rate movements during the period of interest are discussed at length in a series of reports titled, "Treasury and Federal Reserve Ftoreign Exchange Operations." These reports are published in the March, June, September, and December issues of the Federal Reserve Bulletin. 
notable exception occurring between November 1974 and June 1975. This temporary divergence is primarily attributed to a rise in the dollar value of the lira during this period in light of encouraging economic news. In particular, during this period there were three significant developments in Italy: a slowing of the rate of inflation (as evidenced by the flattening out of the Italy WPI line), a decline in the balance-oftrade deficit, and an increase in capital inflows.

However, the situation changed during the last half of 1975 and into 1976. Renewed downward pressure on the lira mounted throughout this period as a result of increased uncertainty about Italy's political and economic outlook. There were signs that inflation was intensifying, merchandise imports began to rise, and the country was unable to induce any capital inflows. On top of this, the coalition govermment appeared increasingly fragile and was forced to resign on January 7,1976 . In the face of all of these events, the lira was supported in foreign exchange markets via massive official intervention by the Bank of Italy. However, the Italian government was unable to sustain its intervention measures beyond January 21 and on that date the lira was set free to float on the open market.

Uncertainty over Italy's economic and political outlook was continually nourished through April by an outpouring of bleak economic and political news. This situation is reflected in Chart I by the steep rise in the product line which began after mid 1975 .

However, in early May 1976 the Italian government imposed sweeping exchange restrictions - including a 50 percent deposit scheme on nearly all purchases of foreign currency. The lira appreciated somewhat relative to the dollar as a result of these moves and the product line moved back into alignment with the Italy WPI line. By the beginning of September the effects of the import deposit scheme had begun to dissipate and, in the absence of any further policy initiative by the government, the lira began to move again in a direction consistent with its relatively high rate of inflation; that is, it depreciated against the dollar. As a result, the product line in Chart I began to rise again along a path similar to that traced by the Italy WPI line.

\section{wher owat}

The same three series that were plotted for Italy in Chart I are plotted for the United Kingdom in Chart II. The product line (labeled U.S. WPI $\times \&$ per $\$$ ) follows the same general pattern as the product line

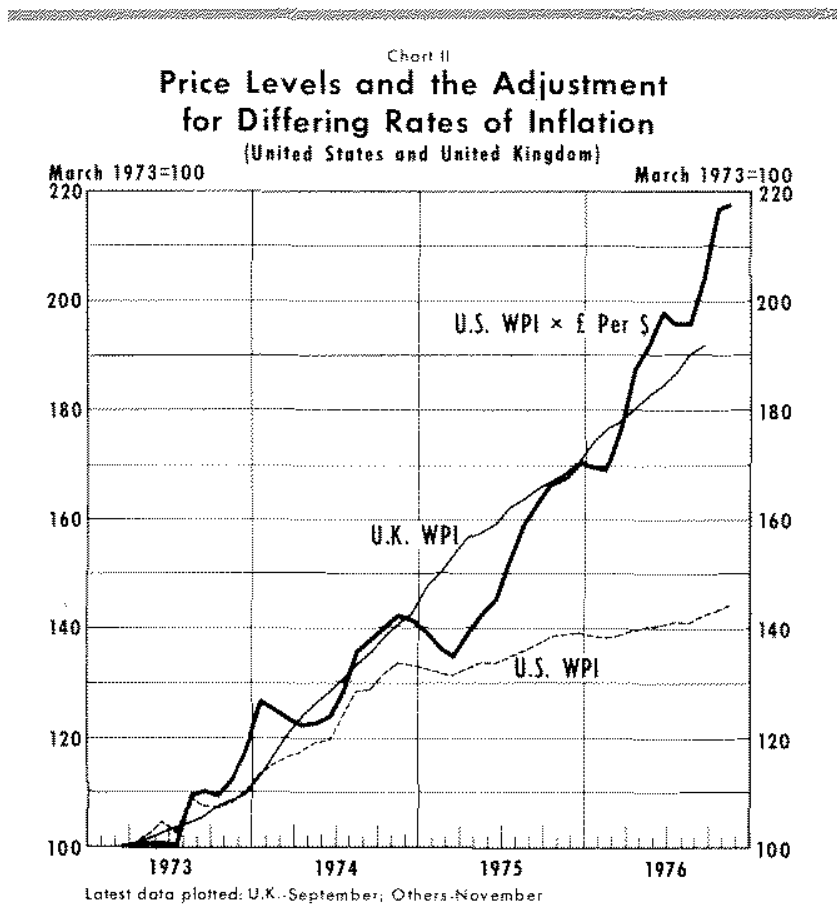

for Italy prior to 1976. That is, it traces the rise in the United Kingdom wholesale price line fairly closely, with the major deviation occurring between November 1974 and March 1975. This divergence reflects a relatively stable pound-dollar exchange rate in the face of a slowdown in the rate of inflation in the United States and unabated inflation in the United Kingdom. The steadiness of the pound vis-avis the dollar during this period is primarily attributable to the poor performance of the U.S. economy, the anticipation of an accelerated decline in U.S. interest rates, and an improvement in Britain's trade account in early 1975 .

However, the pound began to depreciate vis-a-vis the dollar during April 1975. This was the result of new evidence of continued high rates of inflation in the face of continually rising unemployment in the United Kingdom. Moreover, concern mounted that a continuing trend of lower British interest rates would generate large capital outflows. The result of this renewed depreciation was a closing of the gap between the product line and the U. K. WPI line.

The pound stabilized in late 1975 and showed little change in early 1976. The voluntary wage restraint program was having its desired effect and hence was helping to curb the reported rate of inflation. During this period an apparent shift in priorities within the government began to emerge. That is, the government began to talk more about bolstering productivity and 
less about broad social welfare programs. In addition, during this period large interest rate differentials stim* ulated significant inflows of capital. The resulting stability of the pound during this period can be seen in Chart II as a flattening of the product line and its subsequent divergence from the U. K. WPI line.

However, developments in late February 1976 precipitated new doubts about the future of the pound. Economic indicators showed little evidence of a recovery and indicated a likelihood of continuing inflation and still rising unemployment. In addition, interest rates began to decline and thus the differential favoring investments in the United Kingdom began to erode. Given the already uncertain economic and political environment, these factors resulted in renewed depreciation of the pound in early March 1976. As a result, the product line in Chart II surged upward to reach a point considerably above the U. K. WPI line by June.

The economic news coming out of the United Kingdom began to improve in early July, There were indications that both exports and real output were increasing at a faster than anticipated rate and that wholesale price increases were slowing. In addition, there were reports that the government was formulating plans for substantial public expenditure cuts. These factors combined to stabilize the pound-dollar exchange rate during July and August and thus the product line flattened out during that period.

However, a number of factors came to light in late August which precipitated a return of the pound to its downward trend. The release of figures showing increased unemployment during July led to fears that the government's commitment to reduce public spending might be abandoned. In addition, a sharp increase in the U. $\mathrm{K}$. money supply in July was announced. In the face of these developments, the United Kingdom was beginning to feel the effects of the severe summer drought, and the possibility of futher employment and production cutbacks increased as a result. The resulting depreciation of the pound caused the product line to move upward again to a level significantly above the U. K. WPI line.

\section{reseres}

The data series presented in Chart III are similar to those presented in Charts I and II. One difference, however, is that the indices presented in Chart III are on a 1954 base rather than a March 1973 base. Another difference between Chart III and Charts I and II is that it has two different horizontal scales. The

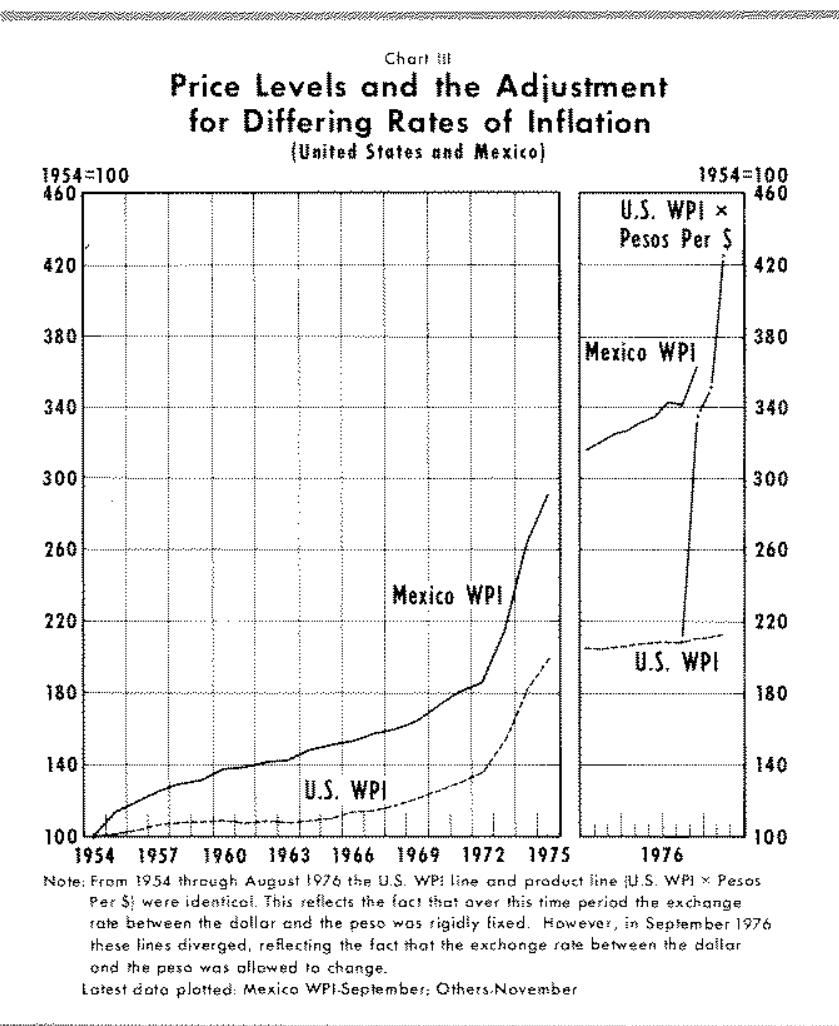

left hand portion of the chart is made up of annual observations (1954-1975) while the right hand portion plots monthly observations (January 1976 - November 1976). The absence of a product line in the left side (annual data side) of Chart III reflects the fact that the peso/dollar exchange rate was not allowed to change between 1954 and August 31, 1976.

The performance of the Mexican peso in the past few months is a grim testimony to the effects of attempts by a government to peg the external value of its currency in the face of an inflation rate which differs significantly from that of a major trading partner. The peso/dollar exchange rate was rigidly pegged at 12.5 pesos/dollar between 1954 and September 1976 . However, as indicated by Chart III, the overall amount of inflation experienced by Mexico between 1954 and 1975 far exceeded that experienced by the United States during this period.

Between 1964 and 1969 the gap between the two WPI lines in Chart III stabilized, indicating that the inflation rate was about the same in the United States as in Mexico during this period. However, since 1973 Mexico's rate of inflation has greatly exceeded that experienced in the United States. As a result, import growth began to far outstrip export growth during the early $1970^{\circ} \mathrm{s}$ and Mexican debt to foreigners began to rise alarmingly. It has been estimated that interest 
costs on this debt anount to at least $\$ 1.8$ billion per year, while total Mexican merchandise export earnings in 1975 were only $\$ 2.9$ billion (verstis an import bill totaling $\$ 6.6$ billion). Thus, the ability of Mexico to service any increased foreign debt came into question and their access to international financial markets was restricted accordingly.

The distressing economic outlook described above, coupled with the political uncertainties surrounding the impending change of goverments on December 1 , precipitated ever increasing downward pressure on the peso. As a result, on September 1, 1976 the Mexian government decided that it had no choice but to allow the peso to float freely on the open market.

The immediate response of the peso was a precipitous decline from 12.5 pesos/dollar to about 20 pesos/ dollar. This decline is indicated by the sharp rise in the product line (labeled U.S. WPI $\times$ peso per $\$$ ) in the right hand section of Chart III. The Bank of Mexico began to intervene in the peso market to peg it at 19.7 pesos/dollar on September 13, 1976. However, continued uncertainty over the political and economic outlook in Mexico resulted in an intensification of capital outflows and downward pressure on the peso. As these pressures mounted, the intervention activities of the Bank of Mexico led to a significant loss of official reserves.

With Mexico's application for a medium-term IMF loan still under negotiation, the authorities decided to allow the peso to float freely again on October 27 . The immediate response was a further depreciation of the peso to about 26 pesos/dollar. This second decline in the value of the peso is indicated by a further rise in the product line in Chart III to a level considerably above the Mexico WPI line.

Throughout November the Bank of Mexico intervened frequently in an attempt to stabilize the peso/\$ exchange rate. However, a series of events, ranging from government expropriation of private land to rumors of a military coup, fueled political uncertainty during this period. Because of reserve losses, and the prospect for even greater losses in the near future, the Bank of Mexico decided to cease all intervention activities as of November 22 . At the same time, temporary regulations which strictly limited commercial bank dealings in foreign exchange were enacted. In the weeks immediately following these actions, the peso reversed its downward trend and rose in value relative to the dollar. However, considerable political and economic uncertainty remains and the market continues to speculate about the course of the Mexican economy under the administration which came into office on December 1.

\section{Whan Throm}

This article has sought to review U.S. international trade and financial developments over the last year or so. In taking such an overview, there is one com mon theme that continually surfaces. That theme relates to the desirability of fixed versus floating exchange rates in the world today.

It is shown in the article that efforts to artificially support a particular exchange rate were doomed to failure. The shocks that resulted from the inevitable large changes in exchange rates were greater than those that would have resulted if exchange rates would have been allowed to change gradually as market pressure developed. On the other hand, the United States policy of maintaining a relatively free market for the dollar insulated this nation from the kind of shocks experienced by Italy, the United Kingdom, and Mexico. ${ }^{10}$ While there was considerable variation in U.S. trade and capital flows during the last year or so, the United States was spared the kind of exchange market crises that were continually plaguing these other countries and that plagued the United States itself from the late $1960^{\circ}$ s until March 1973.

\footnotetext{
"At the close of trading on Decenber 15 the peso was being quoted at 20 peso/dollax. Thtss, it had risen back wp to the level it attaned after the first foat in September. Although Chart III does not cover the events of December, this recent appreciation would imply a dectine of the product line back to about the 340 level.

10In this regard, of a total of $\$ 16$ billion worth of foreign exchange market intervention conducted by governments around the world between August and October 1976, the Federal Reserve was responsible for only $\$ 63.4$ million. Statement by Scott E. Pardee, New York Times, 2 December 1976, p. 80.
}

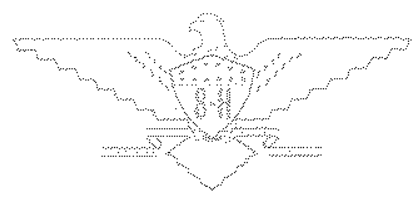

